\title{
Уроки реформирования служб военной разведки в Венгрии
}

\section{Андраш Худик}

Аннотация: Классическими видами служб национальной безопасности являются службы внешней и внутренней разведки, а также объединенные организации, занимающиеся внутренней и внешней разведкой. С профессиональной точки зрения, внешняя и внутренняя разведка не могут считаться полностью независимыми. Некоторые теоретические школы считают внутреннюю разведку (контрразведку) частью разведки; другие видят существенное различие между внутренней и внешней разведкой. Что касается количества служб национальной безопасности, то в странах, сравнимых с Венгрией, в последнее десятилетие наблюдаются две тенденции. Одна из них - это увеличение количества служб, что отражает рост числа и сложности задач и угроз; другая - уменьшение количества служб путем объединения существующих организаций, обычно в силу финансовых причин.

В Венгрии военная внутренняя и внешняя разведка были объединены в 2012 г., с созданием единой организации - Военной службы национальной безопасности (KNBSZ). Хотя перед объединением оценка последствий не проводилась, в официальной оценке Счетной палаты в январе 2014 г. указано, что создание KNBSZ привело к экономии государственных средств, и эта новая организационная форма обеспечила лучшее выполнение прежних задач.

В данной статье коротко представлена нынешняя политическая ситуация в Венгрии, венгерских секретных службах, развитие Сил обороны Венгрии в последнее десятилетие, причины реформирования военных спецслужб, периоды, цели и результаты процесса объединения. В ней содержатся общие и частные выводы и уроки реформирования служб военной разведки в Венгрии.

Ключевые слова: военные, разведка, внешняя разведка, внутренняя разведка, контрразведка, реформа военной разведки, полученные уроки, Венгрия, политическая ситуация, Силы обороны Венгрии, службы национальной безопасности. 


\section{Вступление}

\section{Службы национальной безопасности}

В целом мы различаем два вида служб национальной безопасности. Один из них - служба внутренней разведки (или контрразведки), которая собирает и обрабатывает информацию о внутренней безопасности страны. Ее задача - защита государства, территории и общества от внешнего вмешательства (диверсий, шпионажа, политического насилия). Информация, собранная этой службой, помогает сберечь и гарантировать внутреннюю безопасность государства и общества. Другой - служба внешней разведки, цель которой - узнать о вероятности и последствиях событий внешнего происхождения, представляющих угрозу для страны. Таким образом, эти службы собирают информацию, касающуюся иностранных правительств, организаций, неправительственных объединений, разведывательных служб или агентов иностранных государств, представляющих угрозу или потенциальную угрозу для страны и ее внешних интересов. Информация, собранная службами внешней разведки, способствует реализации национальных интересов, включая политические, экономические, военные, научные и общественные интересы.

Поэтому задачи и цели у этих двух видов служб сбора информации разные. Характер и масштаб угроз, с которыми они имеют дело, тоже разный. Системы управления, контроля и надзора за этими службами должны учитывать эти различия. Поскольку служба внутренней разведки (контрразведки) государства собирает информацию о собственных гражданах, преимущественно внутри страны, ее деятельность требует строгого контроля. Он нужен для того, чтобы интересы сдерживания не превалировали неограниченно над правами граждан и юридических лиц.

Разведывательные, или же информационные организации (внутренняя и внешняя разведка) обычно выполняют три главные задачи: сбор информации, ее анализ, и внутренняя защита этой деятельности (защита от явлений, угрожающих ее собственной работе).

Тайные действия также являются деликатным, но, без сомнения, необходимым элементом деятельности разведывательных служб современных демократических государств. ЦРУ определяет тайные действия как операции, которые оказывают влияние на правительства, события, деятельность организаций и отдельных граждан при осуществлении внешней политики таким образом, чтобы заказчик этих операций не предавался огласке. ${ }^{1}$ Между деятельностью служб внешней и внутренней разведки никогда не

1 DCAF, Рабочая группа по контролю над деятельностью спецслужб, «Деятельность спецслужб и демократический контроль - точка зрения профессионала», Женевский центр демократического контроля над деятельностью сил обороны, Вестник №3, русское издание (Женева, июль 2003): 12-13, 17, 28, https://www.dcaf.ch/sites/default/files/publications/documents/op03_intelligencepractice_ru.pdf. 
было четких границ. Обе видят борьбу с терроризмом, организованной преступностью, оборотом наркотиков и контрабандой своей задачей, в стране и за рубежом. Как разъясняет Рабочая группа DCAF по контролю над деятельностью спецслужб:

Оправданной необходимостью может быть создание централизованной службы, поскольку безопасность страны может быть обеспечена только путем тесного сотрудничества служб внутренней и внешней разведки. Если, например, группа экстремистов планирует вооруженное нападение на страну и собирает информацию для его осуществления, выявить это должна внутренняя разведка. Если указанная группа получает поддержку от соседнего государства в виде помощи в непосредственной подготовке нападения и обучения участников на территории соседнего государства, выявить это уже обязана внешняя разведка. В такой ситуации только централизованная, объединенная организация, координирующая деятельность служб внешней и внутренней разведки, может эффективно отреагировать на угрозу. ${ }^{2}$

Согласно жесткой и ныне устаревшей модели сектора, которой придерживаются всего в нескольких странах, разведка - лишь одно из внешних направлений обеспечения национальной безопасности. Однако согласно современным представлениям, разведка - это основной вид деятельности, главная задача и метод всей национальной безопасности, то есть «секретных» служб - то, что венгерский закон называет «тайным сбором информации». Это означает, что внутренняя и внешняя разведка выполняют общую задачу, а именно сбор информации. Не внешняя или внутренняя направленность отличает службы внутренней и внешней разведки, а место действия (в стране или за рубежом), а также оперативные, технические и организационные аспекты. Например, строгое соблюдение мер оперативной безопасности и требований конспирации одинаково важно в стране и за рубежом, но оно достигается в разных условиях и, частично, разными методами.

\section{Службы национальной безопасности Венгрии}

\section{Венгрия в 2020 году - Политическая ситуация}

Временный упадок гегемонии неолиберализма в ряде стран Центральной Европы после 2008 года привел к волне популизма в этих странах. Популистские партии и движения объединили как левых, так и правых. Одной из немногих их общих черт является то, что они критикуют правящую элиту и ее идеологию, заявляя, что элита подавляет народ и нацию. Согласно левой риторике, социально-экономическая политика популистского правительства Орбана укрепляет капиталистический класс нации, продавая дешевую рабочую силу иностранным промышленным инвесторам, принуждая к дис-

2 DCAF, «Деятельность спецслужб и демократический контроль». 
циплине рабочих и централизованно управляя бедняками, живущими преимущественно в сельских районах. Цель его культурной политики - продвижение официальной венгерской идеологии периода до 1938 года: консервативной, христианской, националистической идеологии, с исторической ложью, несправедливой социальной системой, враждебной атмосферой и (пока еще скрытым) намерением вернуть территории, утраченные после Первой мировой войны. Орбан рассматривает неолиберальный Европейский Союз, тайный сговор международных капиталистов, олицетворяемых Джорджем Соросом, и мигрантов как врагов с тем, чтобы объявить врагами нации своих политический оппонентов и взять на себя роль ее спасителя. Хотя правительство громко критикует некоторые ценности ЕС на политических форумах, в экономических процессах оно подчинено европейским капиталистам. ${ }^{3}$

В связи с политикой построения нового националистического режима Виктора Орбана в Венгрии были ограничены демократия, верховенство права и плюрализм, что привело к появлению страны с нелиберальной демократией. Власть имущие в Венгрии считают, что левые и либералы не являются частью нации, и что все левое и либеральное, будь то человек, произведение искусства или просто точка зрения или мнение, должно считаться чуждым и отбрасываться, поскольку это противоречит официальному национально-христианскому консервативному курсу.

Политические взгляды Орбана откровенно выражены в его выступлении 20 августа 2020 года на церемонии открытия Монумента национального единства в память о Трианонском мирном договоре 1920 года. Премьерминистр Орбан в своей речи заявил, что «Западная Европа, ослабленная проникновением идей безбожного космоса, радужных семей, миграции и открытых обществ, утрачивает свое ведущее положение в мире и становится все менее привлекательной для центральноевропейцев». Он призвал центральноевропейские страны, желающие сохранить свое христианское наследие, создать мощную коалицию, которая сможет помочь переустроить Европу. Орбан добавил, что главный урок минувшего столетия заключается в том, что нации должны бороться и показывать свою силу, чтобы сохранить свою свободу и суверенитет. Орбан сформулировал семь принципов национально ориентированной политики Венгрии в XXI веке: родина существует только до тех пор, пока кто-то ее любит; каждый венгерский ребенок - новый «страж»; правда мало чего стоит без силы; венграм останется только то, что они смогут защитить; «каждый матч продолжается до нашей победы»; границы имеет страна, а не нация; ни один венгр не должен чув-

3 Tamás Gerőcs - Csaba Jelinek, “A Nemzeti Együttmúködés Rendszere az Európai Unióban - Magyarország EU-integrációjáról - történeti szociológiai megközelítésben", Analízis (2018): 12-33, стр. 23, http://www.regscience.hu:8080/xmlui/bitstream/ handle/11155/1768/jelinek_nemzeti_2018.pdf. 
ствовать себя одиноким. ${ }^{4}$ Соответственно, Венгрия вкладывает большие средства в развитие своих сил обороны и модернизацию служб национальной безопасности.

\section{Службы национальной безопасности Венгрии - краткий историче- ский обзор}

После падения бывшего просоветского режима в Венгрии были созданы пять служб национальной безопасности: Бюро национальной безопасности (NBH, гражданская служба контрразведки); Информационное бюро (IH, гражданская служба внешней разведки); Бюро военной безопасности (KBH, военная контрразведка); Бюро военной разведки ( $K F H$, внешняя военная разведка); и Специальная служба национальной безопасности (NBSzSz), отвечающая за специальные средства и методы тайного сбора информации для заказчиков - других служб безопасности (например, перехват линий связи). NBSzSz была отделена от других ведомств, чтобы обеспечить равномерное распределение обязанностей между ними.

Министр без портфеля осуществлял контроль за гражданскими службами национальной безопасности (NBH, IH и NBSzSz), а службы военной разведки подчинялись Министру обороны. Со временем Бюро национальной безопасности было переименовано в Бюро защиты конституции $(A H)$. Кроме того, в 2010 г. был создан Контртеррористический центр (TEK), подчиненный Министру внутренних дел, путем объединения задач сбора информации о терроризме и оперативного реагирования на террористические акты. Организация с таким набором обязанностей уникальна для Европы. Под эгидой Министра внутренних дел была создана новая организация для борьбы с коррупцией в правоохранительных органах, включая службы национальной безопасности, путем реорганизации существовавшей ранее организации с аналогичными обязанностями - Служба защиты правоохранительных органов (RSZVSZ). Полномочия RSZVSZ впоследствии были расширены, а название изменено на Национальную службу защиты (NVSZ). Парламентский контроль над этими службами осуществлял и будет осуществлять Комитет по обороне и деятельности правоохранительных органов и Комитет по национальной безопасности.

Имея две трети голосов в парламенте, правительство Орбана внесло существенные изменения в систему национальной безопасности страны во время второго и третьего срока полномочий. Вскоре после формирования второго правительства Орбана, положение Закона о Национальной безопасности, запрещавшее Министру внутренних дел контролировать гражданские службы национальной безопасности, было упразднено. Это изменение положило конец общественной договоренности и стало явным возвра-

4 Viktor Orbán, "West 'Lost Its Appeal,' Hungarians 'Champions of Survival'," MTIHungary Today, August 20, 2020, https://hungarytoday.hu/orban-speech-august-20survivors-west-central-europe. 
том к прежним временам, когда Министр внутренних дел был главным защитником режима. Бюро защиты конституции и Специальная служба национальной безопасности были поставлены под контроль Министра внутренних дел. Полномочия полиции по осуществлению тайного сбора информации были расширены. Пост Министра без портфеля, отвечавшего за гражданские разведывательные службы, был ликвидирован, что нарушило общий контроль правительства за гражданскими службами. Информационное бюро было в конечном счете подчинено Министру иностранных дел. Удивительно, но Министр внутренних дел был назначен руководителем рабочей группы правительства, занимавшейся украинским кризисом. Профессионализм рабочей группы был поставлен под сомнение, когда на волне сокращений ряд экспертов выдающихся способностей, учившихся в бывшем СССР, владевших соответствующими языками и знакомых с российской и украинской культурой, были уволены из Военной службы национальной безопасности (KNBSZ). В разгар кризиса беженцев 2015 г. парламент передал право объявлять чрезвычайное положение в связи с беженцами от президента республики правительству (Министру внутренних дел). Пограничные войска были подчинены полиции.

После внесения изменений в Закон о Национальной безопасности был создан Центр антитеррористической информации и анализа преступности (TIBEK), подчиненный Министру внутренних дел, получивший особые функции в области национальной безопасности (комплексный анализ и оценка, координация, распределение задач, оценка исполнения). Ведомство с такими функциями требовало централизованного правительственного, а не министерского контроля. Поэтому в 2018 году, чтобы уравновесить растущие полномочия Министра внутренних дел, контроль над TIBEК был передан Государственному секретариату по национальной безопасности, созданному в аппарате Премьер-министра. TIBEK, как «информационный центр», должен был быть создан путем изменения Закона CXXV 1995 г. (Закон о Национальной безопасности), а не отдельным законодательным актом. В то же время было бы логичней создать объединенный орган для анализа, оценки, координации, распределения задач и оценки исполнения под управлением Премьер-министра (например, Центр информационного анализа и оценки национальной безопасности) и подчинить Центр антитеррористической информации и анализа преступности Министру внутренних дел, возможно - руководителю Национальной полиции, но с ограниченными полномочиями и детальным правовым определением обязанностей взаимодействия.

Орган контроля национальной безопасности, созданный в связи с членством Венгрии в НАТО для выполнения требований норм безопасности Альянса, был интегрирован в структуру Министра внутренних дел во время нового срока полномочий правительства, начавшегося в 2014 г., как ведомственная организация. Тем самым Министр внутренних дел получил контроль над международным обменом конфиденциальной информацией 
Министерства иностранных дел и Министерства внутренних дел, при этом исключая себя из-под независимого надзора за конфиденциальностью. На рубеже 2011-2012 гг. правительство достигло своей давней цели, объединив две военные службы национальной безопасности, а именно Бюро военной разведки и Бюро военной безопасности.

На Рис. 1 показаны службы национальной безопасности Венгрии, действующие по состоянию на 2020 год, и характеристики этих служб.

\section{Интеграция Служб военной разведки}

\section{Развитие Сил обороны Венгрии}

Силы обороны Венгрии - официальное название венгерских вооруженных сил. С 2007 г. вооруженные силы находятся под объединенным командованием. Политический и гражданский контроль над армией возложен на Министерство обороны. Подчиненное ему Командование объединенных сил координирует и командует частями и соединениями Сил обороны Венгрии. На действительной военной службе в Силах обороны Венгрии находилось 28000 человек. В 2019 г. военные расходы составили \$1,904 млрд., или примерно 1,2\% ВВП страны - намного ниже ориентира НАТО в 2\%. Военная служба добровольна, хотя в военное время возможен призыв. Согласно венгерской Конституции, безопасность нации опирается на три устоя мощь Сил обороны Венгрии, систему Альянса и граждан.

Венгерское правительство ставит целью сделать вооруженные силы одними из "решающих» в регионе. Бо́льшим силам будет обеспечен увеличенный бюджет - оборонный бюджет достигнет 2 \% ВВП, или 1 трлн. форинтов, к 2024 г. Программа развития обороны и вооруженных сил под названием «Зрини 2026» (Zrínyi 2026) и увеличенный бюджет позволят получить передовые технологии, которые дадут армии возможности XXI века.

Потенциал национальной экономики дает беспрецедентные за последние 25 лет возможности для развития вооруженных сил. В МО разработаны среднесрочные и долгосрочные стратегии, позволяющие армии адекватно реагировать на нынешние и будущие вызовы. Согласно программе «Зрини 2026», правительство сменит снаряжение солдат, в частности, обмундирование и оружие, и модернизирует сухопутные войска и военно-воздушные силы.

Силы обороны Венгрии в ближайшие годы планируют закупить 40 новых вертолетов (12 вертолетов Ми-24 российского производства в настоящее время проходят комплексную модернизацию в России и вернутся на службу до 2025 г.). Силы обороны Венгрии уже купили два транспортных самолета, которые поступят на вооружение в 2020 г. Они могут доставлять личный состав с вооружением и небольшие грузы, а также будут оснащены оборудованием для выполнения поисково-спасательных задач. Венгрии нужны и бо́льшие самолеты, способные доставлять крупные военные грузы и технику, оснащенные оборудованием для дозаправки в воздухе. 


\section{Аппарат Премьер-министра}

Премьер-министр - Виктор Орбан

Информационный центр

Государственный секретариат по национальной безопасности

\section{Министерство обороны}

министр - Тибор Бенко

\section{Военная служба национальной}

безопасности (традиционная военная служба внутренней и внешней разведки, бюджет 20 млрд. форинтов, штат 1000 сотрудников)

\section{Министерство иностранных} дел и внешнеэкономических отношений

министр - Петер Сийярто

Информационное бюро (гражданская служба внешней разведки, бюджет 12,3 млрд. форинтов, штат 750 сотрудников)

\section{Министерство внутренних дел, министр - Шандор Пинтер}

Бюро защиты Конституции (традиционная служба внутренней разведки, бюджет 10,7 млрд. форинтов, штат 1100 сотрудников)

\section{Центр антитеррористической информации и анализа преступности (для анализа и оценки информации о терроризме, полученной другими службами, бюджет 2,4 млрд. форинтов, штат 130 сотрудников)}

Национальная служба защиты (для выявления коррупционных преступлений в правоохранительных органах, включая службы нац. безопасности, бюджет 5,8 млрд. форинтов, штат 550 сотрудников полиции)

Контртеррористический центр (для ведения внешней и внутренней разведки и выполнения оперативных задач борьбы с терроризмом, бюджет - 18,4 млрд. форинтов, штат - 1500 сотрудников полиции)

Рис. 1: Службы национальной безопасности Венгрии.

В рамках своих обязательств перед НАТО Венгрия заменяет тяжелую технику сухопутных войск. После танков и артиллерии пришла очередь боевых машин пехоты, составляющих хребет боевых возможностей. Один из ведущих европейских производителей техники сухопутных войск создаст совместное с Венгрией предприятие для производства в Венгрии самых современных боевых машин пехоты.

В последние годы военные выделили около 15000 солдат для охраны венгерских границ. За это время вооруженные силы Венгрии приняли уча- 
стие примерно в 40 международных учениях, а около 1000 военнослужащих служили в международных миссиях. Силы добровольного резерва Венгрии численностью 5300 человек развиваются в общенациональную сеть, с подразделениями во всех районах страны. Правительство высоко ценит солдатскую службу, и денежное довольствие с 2015 года выросло более чем на $40 \%$.

Приоритеты развития Сил обороны Венгрии обеспечивают активную поддержку населения и Силы добровольного резерва, достаточную мощь (с заменой техники ВВС и тяжелой техники СВ), повышенную стойкость к гибридным и кибер угрозам и эффективную внутреннюю и внешнюю разведку. Чтобы повысить эффективность внутренней и внешней военной разведки, парламент в 2011 г. принял решение о слиянии двух служб военной разведки.

Перед тем, как перейти к процессу объединения, его последствий и результата, я по очереди расскажу о военных секретных службах.

\section{История Бюро военной безопасности}

При смене социальной системы организация, личный состав и методы работы III/IV Управления Министерства внутренних дел (Управление внутренней военной разведки) фактически перешли к правопреемнику - Бюро военной безопасности (KBH). В то время политическое и экономическое руководство страны нуждалось в знаниях опытных, подготовленных сотрудников внутренней военной разведки.

«Смена режима» в 1989-90 гг. существенно не повлияла на КВН. Представление организации о «враге» фактически осталось неизменным: она продолжала заниматься проверкой надежности своих офицеров внешней разведки и выявлять деятельность военной разведки всех зарубежных стран.

Бюро военной безопасности переживало звездные часы под руководством Штефана Гезы, который стал генеральным директором в 1994 г. и занимал эту должность 15 лет - беспрецедентное достижение в истории государственного управления Венгрии.

Уйдя в отставку генералом армии, он продолжал руководить Бюро, как «гражданский сотрудник», и с каждой сменой правительства умудрялся заслужить и сберечь доверие и высокую оценку обеих ведущих партий - Социалистической партии и Молодых демократов (FIDESZ).

Кроме того, будучи прекрасным специалистом по национальной безопасности, который учился в Советском Союзе и был знаком с русскими, он одновременно пользовался расположением новых западных союзников и Москвы. Поэтому он стал своего рода связующим звеном между бывшими противниками времен «холодной войны», объединяя усилия секретных служб России и НАТО в борьбе против глобальных угроз, таких как распространение ОМП, терроризм, незаконная торговля оружием и организованная преступность. 
Однако согласно распространенному в секретных службах мнению, его успехи реально объясняются тем, что он тщательно хранил личные дела бывших информаторов, полученные на его предыдущей должности в Управлении внутренней безопасности Министерства внутренних дел, что доказывает, что значительная часть «новой» венгерской политической и экономической элиты тайно сотрудничала с этим Управлением. Хотя подтверждения такой точки зрения нет, по меньшей мере странно, что венгерский парламент так и не принял так называемого «закона об агентах», предусматривающего раскрытые имен бывших агентов госбезопасности.

В истории Бюро военной безопасности были и черные страницы, такие, как соучастие в мафиозных преступлениях, связанных с импортом нефти, и серийные убийства цыган, а также попытка «занять» Бюро военной разведки на рубеже веков, когда заместителя генерального директора при поддержке правительства временно перевели из Бюро военной безопасности в Бюро военной разведки. Тогда эта попытка провалилась, но была с полным успехом повторена вторым правительством Fidesz путем слияния двух военных служб в 2011-2012 гг. ${ }^{5}$

Организационная структура Бюро военной безопасности в 2011 г., до объединения, была следующей: Юридический и финансовый отдел, Отдел внутренней безопасности, Отдел кадров, Учебный отдел, Бюро национальной безопасности (с неизвестными общественности заданиями) и Архив были прямо подчинены генеральному директору. Административный отдел, Оперативный отдел, Информационно-аналитический Отдел и Отдел личной и производственной безопасности находились в ведении заместителя генерального директора, подчинявшегося непосредственно генеральному директору.

\section{История Бюро военной разведки}

Предшественник Бюро военной разведки, Второе управление (внешней разведки) Генерального штаба Венгерской народной армии, занимал весьма видное место среди служб военной разведки стран-участниц бывшего Варшавского договора. Связано это с так называемым делом Конрада. ${ }^{6}$ Конрад был начальником секретного отдела 8-й пехотной дивизии США, базировавшейся в Германии, и суперагентом шпионской сети, названной его именем. Венгерская внешняя военная разведка завербовала его в 1975 г. при помощи другого американского солдата венгерского происхождения Золтана Сабо, ветерана вьетнамской войны. Сабо был успешно взят в разработку Вторым управлением Генерального штаба Венгерской народной армии в 1971 г.

5 Naive Balfácán, "The Fifth Generation of Traitors," National Security Reading Diary, October 19, 2018, 1-2 и 8-9, https://naivbalfacan.blog.hu/2018/10/19/102_epizod 499\#more14309193 и https://drive.google.com/open?id=11EqiL8uCN3G-_D6tF73cro Or07XbRuRf.

6 Balfácán, "The Fifth Generation of Traitors." 
Сабо служил в Бад-Кройцнахе, откуда и знал Конрада, и оба они воспользовались возможностями, открывшимися им благодаря недостаткам в работе секретного отдела 8-й дивизии. Конрад массово выносил (и вносил обратно) совершенно секретные документы из секретного отдела и передавал копии (а иногда - «списанные» оригиналы) венгерской внешней военной разведке через братьев Керчик. Братья Керчик были врачами, жившими в Швеции. Они много путешествовали по Европе и перевозили «материалы» в Вену в своих медицинских сумках, которые они передавали на тайных встречах офицеру 2-го управления Генерального штаба.

Почти 20 лет группа Конрада передавала бесценную информацию венгерской, а через нее - советской военной разведке, нанося большой ущерб безопасности США, Германии и НАТО в целом. Переданные документы включали оригиналы военных оперативных (оборонных) планов НАТО, подробные данные об организации, вооружении, боевой готовности, системах дежурства ядерных сил и расположении ядерных фугасов. Имея эту информацию, Советы могли быстро оккупировать всю Западную Европу, нанеся неожиданный удар, а Соединенные Штаты могли избежать этого, только будучи готовыми развязать мировую ядерную войну с Советским Союзом.

В период социальных изменений Венгрия нуждалась в благосклонности США, и дело Конрада раскрылось в наихудший момент в 1980-х гг. С профессиональной точки зрения, это был наибольший успех в истории венгерской военной разведки, но политически это стало самым тяжелым и неприятным наследием режима Кадара. В результате правительству пришлось публично извиняться и выражать сожаление из-за того, что, передавая разведывательную информацию Советскому Союзу, Венгрия поставила под угрозу безопасность США и Западной Европы.

После смены режима сокращение штатов Сил обороны Венгрии в течение ряда лет больно ударило по правопреемнику 2-го управления Генерального штаба и, как следствие, Бюро военной разведки. К лету 2007 г. первоначальный штат сократился с 1963 до 733 человек. В то время, по инициативе генерального директора Бюро военной разведки, Министр обороны приказал полностью пересмотреть его деятельность для выполнения растущих международных обязательств и улучшения сбора и предоставления информации. После проверки 2008 г. в подчинении генерального директора Бюро военной разведки были сформированы следующие отделы и подразделения: Отдел агентурной разведки (HUMINT); Отдел радио- и радиотехнической разведки (SIGINT); Информационно-аналитический отдел; Отдел кадров; Секретный и административный отдел; Отдел обеспечения, развития и финансов; Отдел планирования и координации; Секретариат по национальной безопасности (с неизвестными заданиями); аппараты атташе. Бюро военной разведки руководило аппаратами военных атташе в 19 странах, а всего наши военные дипломаты были аккредитованы в 56 стра- 
нах. Эта цифра менялась, и продолжает меняться, в связи с развитием военных отношений, ситуацией с безопасностью и бюджетными соображениями. Аппаратами военных атташе руководит Министр обороны через заместителя госсекретаря по оборонной политике Министерства обороны и генерального директора Бюро военной разведки (в настоящее время - Военной службы национальной безопасности). Совместительство (военный атташе, представляющий Министерство обороны Венгрии в одной зарубежной стране, одновременно аккредитован в других странах) и региональные военные атташе (находящиеся в Будапеште и регулярно посещающие страны, где они аккредитованы) позволяют выполнять задачи военной дипломатии при рациональном использовании средств.

\section{Слияние служб военной разведки}

По решению политических руководителей, к 2011 г. понадобилась единая организация для должного руководства деятельностью военной разведки и контрразведки при более бережном использовании бюджета. (В долгосрочном плане ожидаемая экономия только от избавления от имущества, используемого двумя предшествующими организациями, составляла сотни миллионов форинтов). Объединение проходило в два этапа. Первый этап продолжался с августа по ноябрь 2011 г. со следующими целями: создать условия для ускорения передачи информации; содействовать более эффективному использованию ресурсов; покончить с дублированием усилий для повышения эффективности операций; повысить эффективность защиты венгерских войск, задействованных в операциях; использовать меньше имущества и за счет этого сократить расходы. Период с 1 января по 30 апреля 2012 г. можно назвать вторым этапом объединения, характеризующимся следующими задачами по созданию новой оргструктуры: развитие общего руководства деятельностью военной разведки и контрразведки; оптимизация уровней управления и руководящих должностей; пересмотр внутренних правил и системы должностных инструкций; пересмотр соглашений о сотрудничестве; тыловая, кадровая и техническая интеграция. ${ }^{7}$ Была разработана новая Организационная и операционная политика, отвечающая требованиям закона. В ней детально изложены функции Военной службы национальной безопасности (KNBSZ) и основные правила, регламентирующие ее организацию, управление и работу согласно действующего законодательства.

Что касается парламентского надзора, то демократический контроль осуществляет парламентский Комитет по обороне и деятельности правоохранительных органов и Комитет по национальной безопасности.

7 Kenedli Tamás, "The Most Important Features of the Professional Development of the Military National Security Service in Recent Years," National Security Review (2020): 74-94, https://folyoirat.ludovika.hu/index.php/nbsz/article/view/1397. 


\section{Расширение функций KNBSZ}

Измененный Закон о Национальной безопасности добавил новую задачу к деятельности KNBSZ в сфере национальной безопасности. Ранее эта задача не включалась в число обязанностей всех предшествующих организаций. Новая обязанность KNBSZ - сбор информации о кибер деятельности во вред интересам обороны. Главная задача нового организационного подразделения, ответственного за указанную выше работу - решать проблемы, возникающие перед информационными системами, и предотвращать хакерские атаки, вредящие интересам национальной обороны и безопасности. ${ }^{8}$ Для выполнения предусмотренных законом требований 1 марта 2016 г. был создан Центр киберзащиты. Имея в своем составе три отдела, он способен выполнять все виды деятельности, связанной с урегулирование инцидентов, осуществлением своих полномочий, а также оценкой и анализом уязвимостей. ${ }^{9}$

Управление тактической разведки KNBSZ, основанное 1 июня 2014 г., взяло на себя обязанности Управления тактической разведки Генерального штаба Вооруженных сил, распущенного тот же день. После этой реорганизации возможности тактической разведки Сил обороны Венгрии и возможности стратегической разведки Министерства обороны были поставлены под единое профессиональное руководство, и генеральный директор KNBSZ осуществляет профессиональный контроль за силами и средствами тактической разведки Сил обороны Венгрии. Это решение позволило централизовать управление и децентрализовать ведение разведывательной деятельности на тактическом и стратегическом уровне.

Появились новые возможности для электронной специализации в Силах обороны Венгрии, что позволило создать и развить новые направления разведки (например, возможности видовой разведки (IMINT), возможности обнаружения движущихся наземных целей).

Нынешняя структура Военной службы национальной безопасности показана на Рис. 2.

\section{Выводы, заключения и извлеченные уроки}

В своем отчете об объединении двух служб военной разведки от января 2014 года Государственная счетная палата (ÁSZ) отмечала: «В целом можно сказать, что создание KNBSZ привело к экономии государственных средств, и в то же время, учитывая, что основные задачи остались неизменными, а штат сокращен, была создана более эффективная организационная структура, что создало условия, необходимые для дальнейшего совершенствования профессиональной деятельности». В качестве одного из замечаний к

8 Gergely Szentgáli, "Csendben szolgálni. A magyar nemzetbiztonsági szektor helyzete és átalakítása 2010 és 2014 között - 2. rész," Military Science, no. 3-4 (2015): 84-86, https://core.ac.uk/download/pdf/42939777.pdf.

9 Szentgáli, "Csendben szolgálni." 


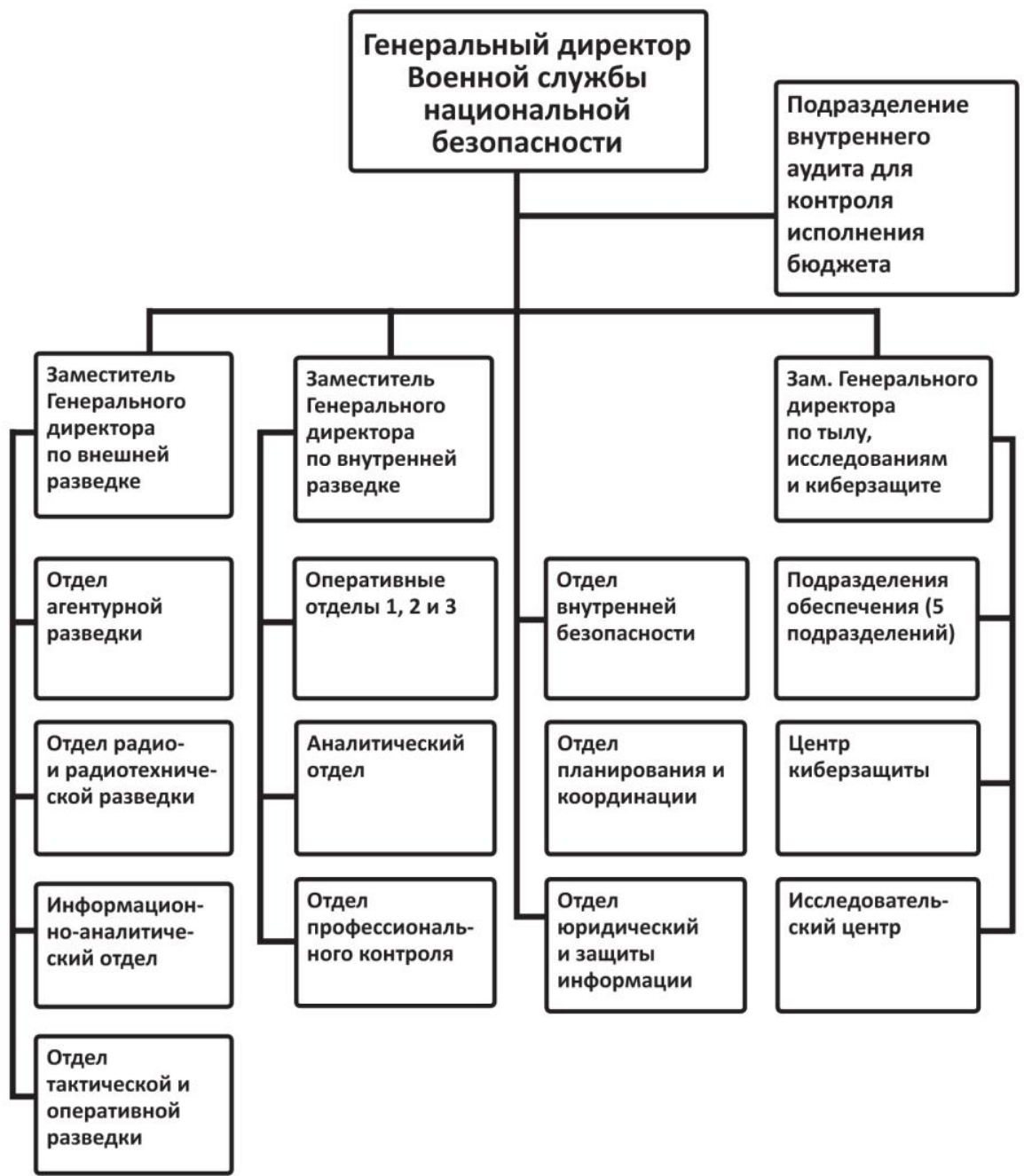

Рис. 2: Структура Военной службы национальной безопасности.

этому отчету можно сказать, что выводы о выполнении специальных профессиональных задач находится вне компетенции ÁSZ, поскольку та не имеет соответствующей квалификации. Другое замечание заключается в том, что подсчеты бюджета противоречат друг другу. Согласно отчету ÁSZ, суммарные расходы Бюро военной безопасности и Бюро военной разведки до слияния в 2011 г. составляли 12 019,5 млн. форинтов, а годовые расходы KNBSZ в 2012 г. остановились на 11 327,0 млн. форинтов. Другими словами, к концу 2012 финансового года (первый год KNBSZ) работа новой организа- 
Таблица 1. Годовой бюджет Бюро военной безопасности (КВН), Бюро военной разведки (KFH) и Военной службы национальной безопасности (KNBSZ) в 2010-2018 rг. ${ }^{10}$

\begin{tabular}{|lrrrrrrrrr|}
\hline \multicolumn{2}{c}{2010} & 2011 & 2012 & 2013 & 2014 & 2015 & 2016 & 2017 & 2018 \\
\hline KBH & 2,5 & 2,6 & & & & & & & \\
\hline KFH & 9,2 & 9,4 & & & & & & & \\
\hline B cymme & 11,7 & 12,0 & & & & & & & \\
\hline KNBSZ & & & 11,3 & 10,9 & 10,4 & 14,9 & 18,5 & 34,6 & 28,2 \\
\hline
\end{tabular}

ции позволила сэкономить 692,5 млн. форинтов, которые в основном можно отнести на счет сокращения штатов. ${ }^{11}$

Поскольку достоверность отчета ÁSZ не следует подвергать сомнению, мои выводы сводятся к нескольким замечаниям: ранее в Бюро военной разведки работало 733 человека, а в Бюро военной безопасности насчитывалось 225. Незадолго до слияния штат первой организации сократили на 155 человек (21,15\%), второй - на 62 (27,56\%). В ранее существовавших организациях были проведены сокращения персонала, и связанные с этим существенные расходы не повлияли на бюджет KNBSZ 2012 г. Финансовые эксперты утверждают, что сокращение штатов служб поддержки и материально-технического обеспечения операций привело к годовой экономии в 1,55 млрд. форинтов. Если принять это во внимание, экономия в бюджете 2012 г. представляется весьма умеренной. Это выглядит тем более удручающе, если мы рассмотрим еще и бюджет аппаратов атташе. Согласно отчету ÁSZ, если средние расходы примерно двадцати аппаратов атташе принять за 100 единиц в 2010 г., эти расходы составили 120,2 единицы в 2011 г. и 85 единиц в 2012 г., что должно было также привести к существенной экономии.

Вывод о том, что создание KNBSZ привело к экономии государственных средств, несомненно, верен; однако в первый год существования KNBSZ эта экономия не соответствовала ожиданиям.

Оценка деятельности KNBSZ рассмотрена в нескольких венгерских исследованиях, ${ }^{12}$ и в этих исследованиях последовательно и твердо утверждается, что слияние было успешным и повысило стандарты разведывательной и контрразведывательной деятельности. Не подвергая сомнению выводы

10 Tamás, "The Most Important Features of the Professional Development;" Szentgáli, "Csendben szolgálni;" State Court of Auditors, "Report on the Control of the Military National Security Service."

11 State Court of Auditors, "Report on the Control of the Military National Security Service," State Court of Auditors (January 2014), 11, https://www.knbsz.gov.hu/ hu/14018j000.pdf.

12 Balfácán, "The Fifth Generation of Traitors;" Kenedli, "The Most Important Features of the Professional Development." 
указанных исследований, я хочу привести несколько фактов. Во-первых, первоначальная численность личного состава KNBSZ должна быть равной суммарной численности личного состава Бюро военной разведки (578) и Бюро военной безопасности (163) сразу после сокращения штатов (741), в то время как по решению Министра обороны KNBSZ получила дополнительные должности и начала работу с 825 сотрудниками. Неизвестно, когда министр принял это решение - до начала сокращения штатов или после его завершения. Если это решение было принято после сокращения штатов, то увольнение 84 офицеров не было необходимым. Во-вторых, наиболее важные должности с точки зрения проведения объединения (руководство отдела, координирующего внутренние и зарубежные операции, руководящие должности в кадровом и учебном отделе, ответственные за практическое осуществление объединения, а также руководство отдела внутренней безопасности) отошли офицерам Бюро военной безопасности. Как следствие, молодые, высококвалифицированные и владеющие языками офицеры, подофицеры разведки и их гражданские коллеги оказались лишними по надуманным причинам или соображениям безопасности. И наоборот, старшие по возрасту, менее квалифицированные офицеры разведки, не знающие языков, остались. В-третьих, большинство высших руководящих должностей в Военной службе национальной безопасности заняли офицеры Бюро национальной безопасности, хотя, исходя из действующего законодательства и министерских инструкций, Бюро военной безопасности было распущено и влито в Бюро военной разведки, в то время как последняя организация лишь сменила вывеску (став Военной службы национальной безопасности). Такое преобладание военной контрразведки и ее ценностей могло способствовать появлению необоснованного предубеждения и долговременных подозрений в отношении разведывательной деятельности, негативно влияя на эффективность внешней разведки.

Исходя из вышеизложенного, включая радикальное сокращение бюджетов аппаратов военных атташе, я уверен, что в первый год после слияния возможности KNBSZ по ведению внешней разведки существенно сузились, хоть и без ущерба для выполнение главной задачи (постоянный сбор информации в указанных областях).

Самые главные выводы и уроки, полученные в результате реформы венгерских служб военной разведки, таковы:

1. Поскольку служба внутренней разведки (контрразведки) собирает информацию о венгерских гражданах внутри страны, ее деятельность требует пристального контроля. В Венгрии, в отношении Бюро военной безопасности, этот контроль был неэффективным. Поэтому после объединения двух служб военной разведки контрразведка получила лучшие стартовые позиции и приобрела большее влияние в объединенной организации, по сравнению с ее реальным значением. Это обстоятельство могло повлиять на эффективность внешней разведки в последующие годы. 
2. Объединению двух служб военной разведки не предшествовало тщательное изучение последствий, основанное на научных исследованиях. Сокращение штатов проводилось, как у дисциплинированных военных, но кадровые потребности согласно поставленных задач даже не оценивались. Поэтому руководители, проводившие объединение, постоянно сталкивались с финансовыми, кадровыми проблемами и проблемами профессиональной интеграции при объединении и реорганизации. Они пытались найти наилучшие решения просчетов, но это не могло компенсировать недостаточную подготовку реформы. Это должно стать примером, которого следует избегать в любой стране.

3. При объединении двух правительственных служб важно принимать во внимание профессиональные соображения и политически быть полностью нейтральным. Этих принципов также следует придерживаться при назначении членов высшего руководства новой организации. К сожалению, при объединении венгерских военных секретных служб было иначе. Пост заместителя Генерального директора объединенной организации был отдан бывшему «советнику по разведке» правящей партии (Молодые демократы - Fidesz), протеже спикера парламента, без воинского звания и знания какого-либо иностранного языка. Почти полтора года его работы принесли много вреда новой организации. Обстоятельства его замены по-прежнему не ясны. Согласно СМИ, он прослушивал своего руководителя, Министра обороны, и потому должен был уйти в отставку. Кроме того, в секретных службах распространено мнение, что он хотел получить должность генерального директора KNBSZ без координации своих действий со всеми ключевыми фигурам в Fidesz.

4. Главным аргументом в пользу слияния всегда служит стремление избежать дублирования усилий объединяемых организаций. В случае служб военной разведки (военной контрразведки и разведки) такое дублирование возможно, но не настолько, чтобы его нельзя было разрешить путем изменения оперативной и организационной политики соответствующих организаций.

5. Если офицер контрразведки увидит оставленный на столе совсекретный документ, он захочет узнать, кто оставил его на столе. Если тот же документ увидит офицер разведки, он захочет узнать его содержание. Эти две функции требуют двух разных подходов и методологий, не говоря уже о разных чертах характера, необходимых для их выполнения. Если и разведчик, и контрразведчик выполнят каждый свою задачу, вероятно, обоим станет ясно, кто оставил на столе секретный документ и каково его содержание. Официальный взаимный обмен информацией может подтвердить подлинность информации, полученной службами независимо друг от друга. Поэтому объединение военной разведки и контрразведки не является абсолютной необходимостью. Однако необходимость более эффективного противодействия новым типам угроз (например, гибридная война, информационные операции) может оправдывать такое объединение. 


\section{Заключение}

История Военной службы национальной безопасности началась между двумя мировыми войнами. Нынешняя объединенная организация зарубежной (внешней) и национальной (внутренней) разведки была создана в 2012 г. путем слияния Бюро военной разведки и Бюро военной безопасности Венгерской Республики. Несмотря на многочисленные недостатки в подготовке и реализации и на извлеченные уроки, слияние было успешным. В настоящее время организация имеет широкие обязанности: сбор в зарубежных странах военной информации (в том числе - секретными средствами и методами), на которой основываются решения правительства, выявление деятельности зарубежных военных секретных служб в Венгрии и защита от них венгерских воинских частей и соединений, защита личного состава, принимающего участие в операциях по урегулированию кризисов за рубежом, обеспечение национальной безопасности и проверка образа жизни личного состава Службы, сбор информации о терроризме и организованной преступности, киберзащита и научная деятельность. Гражданский контроль над Службой осуществляют Комитет по обороне и деятельности правоохранительных органов и Комитет по национальной безопасности венгерского парламента. Этот парламентский контроль чрезвычайно важен. Без полной публичности невозможно убедить граждан, что деятельность Службы не угрожает их интересам или что она эффективна с бюджетной точки зрения. Однако не чувствуется, что организация имеет надлежащую стратегию коммуникации с обществом. Хотя генеральным директором Службы выданы инструкции касательно внешних связей, и секретный характер службы организации следует признавать, информационное содержание веб-сайта Службы не способствует общественному восприятию и интеграции организации.

\section{Отказ от ответственности}

Выраженные здесь взгляды являются исключительно взглядами автора и не отражают точку зрения Консорциума оборонных академий и институтов изучения безопасности ПрМ, участвующих организаций или редакторов Консорциума.

\section{Об авторе}

Андраш Худик - доктор военных наук, полковник полиции в отставке, старший советник венгерской полиции. Военный инженер, исследователь, политолог. Ранее работал советником в ГУАМ, ОБСЕ, EUBAM и в Совместном механизме расследований ООН-ОЗХО. До работы в международных организациях служил в Бюро военной разведки, Службе защиты правоохранительных органов и Контртеррористическом центре Венгрии.

Электронная почта: seniorhugyik@gmail.com 


\section{Благодарность}

Журнал Connections: The Quarterly Journal, Vol. 20, 2021 издается при поддержке правительства США. 